Provided for non-commercial research and education use. Not for reproduction, distribution or commercial use.

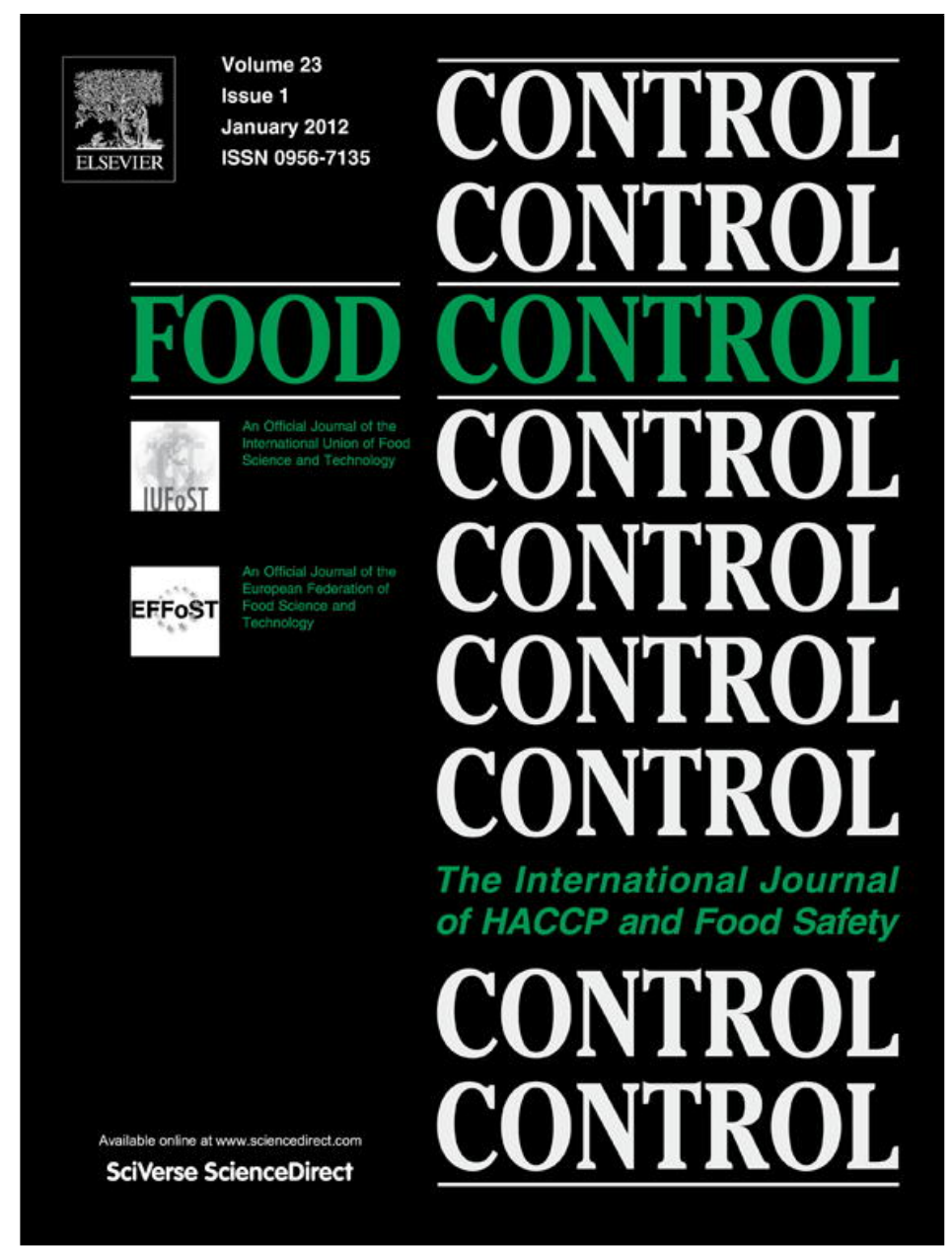

(This is a sample cover image for this issue. The actual cover is not yet available at this time.)

This article appeared in a journal published by Elsevier. The attached copy is furnished to the author for internal non-commercial research and education use, including for instruction at the authors institution and sharing with colleagues.

Other uses, including reproduction and distribution, or selling or licensing copies, or posting to personal, institutional or third party websites are prohibited.

In most cases authors are permitted to post their version of the article (e.g. in Word or Tex form) to their personal website or institutional repository. Authors requiring further information regarding Elsevier's archiving and manuscript policies are encouraged to visit:

http://www.elsevier.com/copyright 


\title{
Antimicrobial activity of lysozyme and lactoferrin incorporated in cellulose-based food packaging
}

\author{
Alberto Barbiroli ${ }^{a}$, Francesco Bonomi ${ }^{a}$, Giorgio Capretti ${ }^{b}$, Stefania Iametti ${ }^{a}$, Matilde Manzoni ${ }^{c}$, \\ Luciano Piergiovanni ${ }^{\mathrm{c}}$, Manuela Rollini ${ }^{\mathrm{c}, *}$ \\ ${ }^{a}$ Dipartimento di Scienze Molecolari Agroalimentari, Università degli Studi di Milano, Via Celoria, 2, I-20133 Milano, Italy \\ ${ }^{\mathrm{b}}$ Stazione Sperimentale Carta, Cartoni e Paste per Carta, Piazza L. da Vinci, 16, I-20133 Milano, Italy \\ ${ }^{\mathrm{c}}$ Dipartimento di Scienze e Tecnologie Alimentari e Microbiologiche, Università degli Studi di Milano, Via Celoria, 2, I-20133 Milano, Italy
}

\section{A R T I C L E I N F O}

Article history:

Received 26 October 2011

Received in revised form

16 January 2012

Accepted 21 January 2012

\section{Keywords:}

Active packaging

Functionalized paper

Lysozyme

Lactoferrin

Antimicrobial

\begin{abstract}
A B S T R A C T
The antimicrobial proteins lysozyme and lactoferrin were incorporated into paper containing carboxymethyl cellulose, that allowed non-covalent binding of the positively charged proteins to the paper matrix. More than 60 percent of the proteins added alone or in combination during the papermaking process were released in buffered saline.

The released proteins retained their structural and functional features, indicating that the papermaking process did not affect their structure. The antimicrobial activity on common food contaminants was also retained in the released protein, and a synergism between the two proteins was evident in tests carried out with paper containing both proteins against Listeria.

Tests on thin meat slices laid on paper sheets containing either or both antimicrobial proteins indicated that lysozyme was most effective in preventing growth of this particular microbiota.
\end{abstract}

(c) 2012 Elsevier Ltd. All rights reserved.

\section{Introduction}

Active antimicrobial packaging could be an alternative solution to prevent develop of spoilage and pathogenic microorganisms in fresh food and to extend their shelf life (Cooksey, 2000; Mastromatteo, Mastromatteo, Conte, \& Del Nobile, 2010). Among the possible strategies used for active packaging, controlled release of antimicrobials from the package itself or from additional release elements placed within the package represent the most common options. A broad range of antimicrobials have received attention, also in consideration of the requirement for the release elements to be non-intrusive, cheap, and compatible with the geometry and physico-chemical properties of food. Whereas volatile antimicrobials (such as essential oils or their active components) have been proposed in the case of foods with a low mass/volume ratio (such as salads), water-soluble antimicrobials have been indicated as most appropriate when direct contact with the food is involved (for instance, meat and meat cuts). In the latter case, the antimicrobial could be released either from the packaging walls, or from layers of suitable materials intercalated between individual cuts or pieces

\footnotetext{
* Corresponding author. Tel.: +39 (0) 2 50319150; fax: +39 (0) 250319238.

E-mail address: manuela.rollini@unimi.it (M. Rollini).
}

(Pérez-Pérez, Regalado-González, Rodríguez-Rodríguez, BarbosaRodríguez, \& Villaseñor-Ortega, 2006).

In view of its properties (cost, acceptance, sustainability) paper may be regarded as an excellent material for controlled release of antimicrobials in active packaging, also taking into account that papermaker are capable of providing products with a broad range of mechanical, physical, and chemical properties. In previous work our group has produced and characterized a cellulose-based active packaging loaded with the well known antimicrobial enzyme lysozyme (Mascheroni et al., 2010). By modulating the anionic charge of the matrix it was possible to bind lysozyme onto (and into) the material via non-covalent interactions. Release of the antimicrobial was dependent on the physico-chemical properties of the packaged food ( $\mathrm{pH}$ and ionic strength).

Lysozyme antimicrobial activity relies on the ability of hydrolyzing the $\beta-1,4$ linkage between $N$-acetyl muramic acid and $N$ acetyl glucosamine present in peptidoglycan. Gram-positive bacteria are very susceptible to lysozyme, because their cell wall is made up for $90 \%$ of peptidoglycan; in Gram-negatives, peptidoglycan counts only for $5-10 \%$ of the cell wall and lies beneath the outer membrane of the cell envelope (Losso, Nakai, \& Charter, 2000). Nevertheless, lysozyme can be effective against Gramnegative bacteria in the presence of membrane destabilizing agents, such as detergents and chelators (Gill \& Holley, 2000). This 
makes lysozyme alone de facto ineffective in the protection of food products where the spoilage is due to Gram-negative bacteria like Enterobacteriaceae and Pseudomonadaceae that are relatively common contaminants of meat-based products (Coma, 2008). A number of studies have proposed the combined use of lysozyme and various agents like EDTA (Cannarsi et al., 2008) or nisin (Gill \& Holley, 2000; Nattress, Yost, \& Baker, 2001). However, Nattress and Baker (2003) reported that dipping pork meat in a solution of nisin and lysozyme was ineffective against Pseudomonadaceae and boosted the growth of Enterobacteriaceae, likely as a consequence of the inhibition of the lactic acid bacteria, that are natural competitors of the Enterobacteriaceae.

To improve the activity of lysozyme toward Gram-negative bacteria, Ellison and Giehl proposed in 1991 its use in association with lactoferrin. Lactoferrin is an $80 \mathrm{kDa}$ whey glycoprotein that can bind 2 ferric ions for each protein molecule. Because of its ability to reversibly bind ions, lactoferrin is naturally a mixture of iron-free (apo-lactoferrin) and of forms containing one or two iron atoms (holo-lactoferrin) (Gonzalez-Chavez, Arevalo-Gallegos, \& Rascon-Cruz, 2009). The antibacterial activity of lactoferrin is due to two different and unrelated mechanisms, one based on iron deprivation that inhibits bacterial growth, and one related to the large cationic patches presents on the lactoferrin surface (Jenssen \& Hancock, 2009). These cationic patches allow direct interaction with the anionic Lipid A, a component of the lipopolysaccharide (LPS) of Gram-negative bacteria, thus altering the outer membrane permeability and resulting in the release of LPS. As a natural component of milk, lactoferrin satisfies all regulatory requirements, and has been used directly in an antimicrobial spray for the treatment of beef carcasses (Taylor, Brock, Kruger, Berner, \& Murphy, 2004).

For the purpose of simultaneous use of lactoferrin and lysozyme, it is worth noting that lactoferrin resembles lysozyme in charge, with pI values of $8-8.5$ for lactoferrin and 11 for lysozyme. This characteristic make lactoferrin a great candidate for being incorporated in a cellulose-based active packaging by using the same strategies developed in our previous work for lysozyme (Mascheroni et al., 2010).

The aim of this study was to prepare and characterize a cellulose-based active packaging material in which lysozyme and lactoferrin were incorporated. We measured the release of both antimicrobial proteins from the paper sheets in which they were incorporated during papermaking, and assessed retention of their original structural and functional properties. The efficacy of the lactoferrin/lysozyme-containing paper was also assessed both by in-vitro microbiological tests and by performing short-term storage trials on thin slices of raw meat.

\section{Materials and methods}

\subsection{Preparation of paper with incorporated antimicrobial proteins}

Paper sheets were prepared according to the international standard ISO 5269-2:2004, using various ratios of long and short fibers in the presence/absence of $10 \%$ sodium carboxymethyl cellulose (CMC, WALOCEL CRT 60000 PPA07, DS 0.7-0.8, Wolff Cellulosic, Schkopau, Germany), retaining its physical and mechanical properties, as reported elsewhere (Mascheroni et al., 2010). Food grade lysozyme (Caglificio Clerici s.p.a., Codorago, Italy) or bovine lactoferrin (Fonterra, Cernusco Lombardone, Italy) were added directly to the slurry used for paper preparation. The amount of total protein was $10 \%(\mathrm{w} / \mathrm{w})$ of the fiber used for papermaking. The slurry was then processed into paper following the procedure described by Mascheroni et al. (2010). Paper sheets were wet pressed and dried under restraint for $2 \mathrm{~min}$ at $90{ }^{\circ} \mathrm{C}$.
Papers containing both proteins were prepared starting from a $1 / 1(\mathrm{v} / \mathrm{v})$ mixture of different slurries, each containing the individual proteins.

\subsection{Quantification of lysozyme and lactoferrin incorporated in and released from the paper}

Lysozyme and lactoferrin incorporation into paper sheets was quantified by SDS-PAGE. The total amount of incorporated proteins (regardless of their denaturation state and solubility) was detected by cutting a $0.5 \mathrm{~cm}^{2}$ sample of paper, that was directly placed into $0.1 \mathrm{ml}$ of denaturing buffer $(0.125 \mathrm{M}$ Tris $-\mathrm{HCl}, \mathrm{pH} 6.8 ; 50 \% \mathrm{w} / \mathrm{v}$ glycerol, $1.7 \% \mathrm{w} / \mathrm{v}$ SDS; $0.01 \% \mathrm{w} / \mathrm{v}$ Bromophenol Blue, $1 \% \mathrm{v} / \mathrm{v} 2$ mercaptoethanol). After $5 \mathrm{~min}$ at $100{ }^{\circ} \mathrm{C}$, the suspension was centrifuged, and an aliquot of the supernatant was used for SDSPAGE on a fixed porosity gel (12\% monomer, XT Mes 20x, BioRad, Richmond, VA, USA), at constant $200 \mathrm{~V}$. Gels were stained with Coomassie Brilliant Blue R250, Intensity of individual bands was assessed by image analysis, and compared for either protein with the intensity of bands obtained with known amounts of the original protein, that were used to construct a calibration curve. Molecular mass markers (BioRad, Novex, Richmond, VA) covered the 3.5-260 kDa range. Release of soluble lysozyme and lactoferrin was detected by soaking $0.5 \mathrm{~cm}^{2}$ of paper in $0.7 \mathrm{ml}$ of $20 \mathrm{mM}$ phosphate, $1 \mathrm{M} \mathrm{NaCl}, \mathrm{pH}$ 7, for $24 \mathrm{~h}$ at room temperature. After centrifugation, a suitable volume of the supernatant was diluted $1 / 9(\mathrm{v} / \mathrm{v})$ with denaturing buffer, following by denaturation and electrophoresis as above.

\subsection{Structural characterization of the released proteins}

Retention of structural and functional features were assessed on the proteins released from each paper sample by soaking in $20 \mathrm{mM}$ phosphate, $1 \mathrm{M} \mathrm{NaCl}, \mathrm{pH}$ 7, for $24 \mathrm{~h}$ at room temperature, as outlined above. Retention of lysozyme tertiary structure was assessed by comparing the fluorescence emission spectra of tryptophan residues in the released and the untreated protein. Tryptophan fluorescence studies were carried out in an LS-50 spectrofluorimeter (Perkin-Elmer, Waltham, MA, USA) with excitation at $280 \mathrm{~nm}$. The absence of changes in secondary structure was verified by $C D$ measurements in the far-UV region using $0.1 \mathrm{~cm}$ path length cells in a JASCO J-810 spectropolarimeter (Jasco Europe) at a protein concentration of $0.2 \mathrm{mg} / \mathrm{ml}$.

In the case of lactoferrin, protein functionality was assessed by assessing its iron-binding properties, evaluated by monitoring the increase in $\mathrm{A}_{465}$ (Lamba 2 spectrophotometer, Perkin-Elmer, Waltham, MA, USA) upon titration of the protein (in $20 \mathrm{mM}$ sodium bicarbonate buffer, $\mathrm{pH}$ 7) with appropriate volumes of aqueous $2 \mathrm{mM}$ ferric ammonium citrate.

\subsection{In vitro antimicrobial activity of paper containing lysozyme and/or lactoferrin}

E. coli DSMZ 50902 (DSMZ: Deutsche Sammlung von Mikroorganismen und Zellkulturen $\mathrm{GmbH}$, Braunschweig, Germany) and L. innocua DSMZ 20649 were used in the research. Strains were grown on TSA medium (Tryptic Soy Agar, Micropoli, Milan), incubated at $37{ }^{\circ} \mathrm{C}$ for $24 \mathrm{~h}$, and then maintained as frozen stocks at $-20{ }^{\circ} \mathrm{C}$ in TSB liquid medium in presence of $10 \%(\mathrm{w} / \mathrm{v})$ glycerol. Cultures were propagated twice before use in experiments.

Lysozyme activity was assessed by applying the procedure outlined by Losso et al. (2000). A suspension ( $1 \mathrm{~g} / \mathrm{l})$ of a cell lysate from Micrococcus lysodeikticus ATCC 4698 (Sigma m3770-5G) was prepared in $0.1 \mathrm{M} \mathrm{pH} 7.0$ phosphate buffer containing $10 \mathrm{~g} / \mathrm{l}$ agar, 
boiled, and poured in Petri plates. After solidification, discs of the various paper materials (18 $\mathrm{mm}$ diameter) were laid on the gel. Plates were then incubated at $37{ }^{\circ} \mathrm{C}$ for up to $24 \mathrm{~h}$ and lysozyme activity was assessed by measuring the diameter of the cell walls lysis area around the paper discs.

Samples of active paper $\left(15 \mathrm{~cm}^{2}\right)$ were placed in $30 \mathrm{ml}$ of TSB in sterile tubes inoculated $(1 \% \mathrm{v} / \mathrm{v})$ with a microbial suspension of either $E$. coli or $L$. innocua having $\mathrm{OD}_{600}=0.200$. Control cultures, without paper, were also set-up. During incubation at $30{ }^{\circ} \mathrm{C}$, culture samples were taken at appropriate intervals for up to $24 \mathrm{~h}$, and bacterial population (log cfu/ml) determined employing the plate count technique. Time course of cell growth in each trial was then fitted employing the DMFit software, to estimate growth rate $\left(\mu \max , h^{-1}\right)$, lag phase duration $(h)$, final population $\left(\mathrm{Y}_{\mathrm{end}}, \log \mathrm{cfu} / \mathrm{ml}\right)$, correlation coefficient $\left(\mathrm{R}^{2}\right)$ and model standard error $\left(\mathrm{SE}_{\mathrm{fit}}\right)$, as predicted by the Baranyi and Roberts equation (1994).

\subsection{Antimicrobial activity of active paper samples on thin-cut veal meat}

Ready-to-eat thin-cut veal meat (meant for consumption as raw food, and known in Italy as "carpaccio") was purchased in a local store. Samples of active paper were placed below individual cuts, in contact with self-absorbent expanded polystyrene trays. Trays were then sealed in aerobic conditions and stored at $4{ }^{\circ} \mathrm{C}$. Sampling was carried out immediately and after 2 days storage. Two set of trials were performed, with and without (control sample) active papers containing the various antimicrobials, alone or in combination.

Individual meat slices (10-12 g) were transferred aseptically into a stomacher bag (400 ml PE, Barloworld, France) containing 90-108 $\mathrm{ml}$ sterile physiological solution $(9 \mathrm{~g} / \mathrm{l} \mathrm{NaCl})$ and blended in a stomacher (Star Blender LB 400, Biosystem) at high speed for $3 \mathrm{~min}$. Ten-fold dilution series of the obtained suspension were made in the same saline solution for plating. Nutrient Agar (Scharlau Chemie, Barcelona, E) was used for total aerobic plate count (TAC), pour plated and incubated at $30{ }^{\circ} \mathrm{C}$ for $48 \mathrm{~h}$. Experiments were replicated twice. Data were transformed into logarithms of the number of colony forming units (log cfu/g meat), and means and standard deviations were calculated.

\subsection{Statistical analysis}

Experiments were performed in triplicate, and obtained data were submitted to two-way analysis of variance. The Tukey-Kramer test was used for the comparison of means, with significance assigned at $P<0.05$.

\section{Results and discussion}

3.1. The incorporation procedure is efficient and allows to retain protein structure and functionality

Given the prospected use of the antimicrobial paper in active food packaging, release of the antimicrobial was of paramount importance. Release of protein was measured after soaking in buffered saline at neutral $\mathrm{pH}$, and quantitation of the released protein was carried out by densitometric analysis of SDS-PAGE gels, shown in the two panels of Fig. 1. Known amounts of the original protein preparation were run in the same gel for calibrating purposes. In the frame of this study, it has to be kept in mind that paper containing both antimicrobials was prepared by mixing individual slurries. Use of mixtures of pre-adsorbed protein for papermaking was meant to minimize possible competition phenomena between the two proteins.

Out of several possible combinations (Table 1 ), the one based on a $80 / 20$ ratio of long/short fibers and containing $10 \%$ CMC gave the most satisfactory results. Table 1 also makes evident the improvement resulting from CMC inclusion in the paper as for binding of positively charged lactoferrin and lysozyme. The amount of protein released from the paper in solutions at high ionic strength, and that trapped in the paper and released only under denaturing and reducing conditions (i.e., after boiling a known amount of paper in detergent and 2-mercaptoethanol) was determined by SDS-PAGE (Fig. 1) and subsequent image analysis. By comparison with appropriate standards, and by taking into account the amount of each protein added to the slurry used for paper preparation, it was possible to evaluate how much of each protein was lost in the paper production process, and how much of each protein remained irreversibly bound to the paper, not being detached upon prolonged incubation at high ionic strength.

With reference to the 80/20/10 paper formulation (long fibers/ short fibers/CMC) discussed above, we calculated that the amount of protein incorporated into the paper was above $60 \%$ of that added to the pulp slurry prior to papermaking $(62 \%$, lysozyme; $66 \%$ lactoferrin), and that about $10 \%$ of the protein adsorbed within the paper structure was not detachable in buffer/saline (8\%, lysozyme; $10 \%$ lactoferrin), likely as a consequence of irreversible structural changes ensuing from the drying step at $90{ }^{\circ} \mathrm{C}$ used in papermaking. The slightly lower recovery for lactoferrin is very likely a consequence of the lower thermostability of this protein and of its larger size in comparison to the highly stable and much smaller lysozyme.

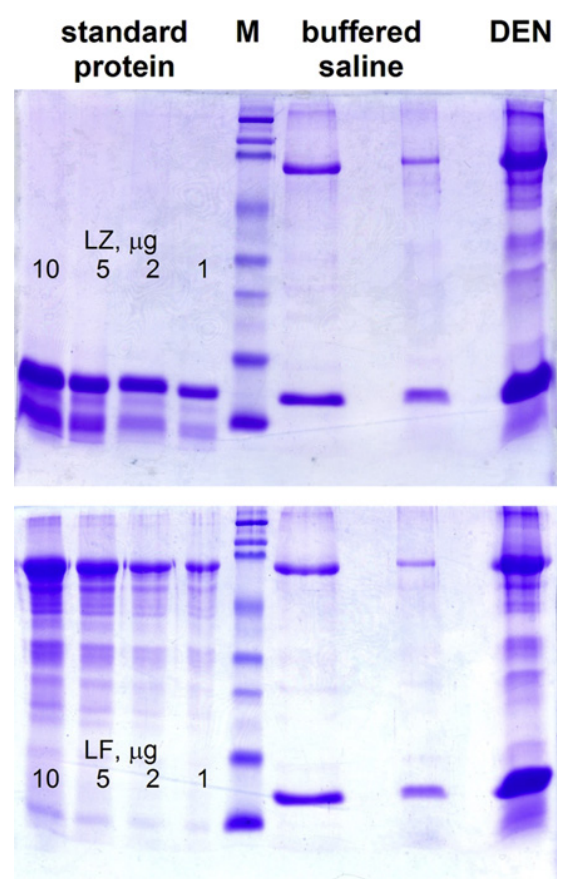

Fig. 1. SDS-PAGE tracings of proteins extracted in various media from paper incorporating lysozyme (LZ) and lactoferrin (LF). Two different volumes of the solution obtained by treating papers with buffer saline were run (lanes indicated as "buffered saline"), and compared with proteins extracted from paper upon boiling in detergent and 2-mercaptoethanol (DEN), and with the given amounts of each standard protein (lanes on the left side of each panel). Molecular weight standards (M) were also run. The representative tracings shown above refer to the paper samples listed in the last two lines of Table 1, in the same order from top to bottom. 
Table 1

Composition, protein binding to, and protein release from various types of paper containing lactoferrin (LF) and lysozyme (LZ).

\begin{tabular}{|c|c|c|c|c|c|c|c|c|}
\hline \multirow{2}{*}{\multicolumn{3}{|c|}{$\frac{\text { Paper composition }}{\text { Type and amount (\%) of fibers }}$}} & \multicolumn{4}{|c|}{ Released protein $\left(\mu \mathrm{g} / \mathrm{cm}^{2}\right)$} & \multirow{2}{*}{\multicolumn{2}{|c|}{$\begin{array}{l}\text { Protein binding, \% of the amoun } \\
\text { added prior to papermaking }\end{array}$}} \\
\hline & & & \multicolumn{2}{|c|}{ In buffer/saline } & \multicolumn{2}{|c|}{ Under denaturing conditions } & & \\
\hline Long & Short & CMC (\%) & $\mathrm{LF}$ & $\mathrm{LZ}$ & $\overline{\mathrm{LF}}$ & $\mathrm{LZ}$ & $\mathrm{LF}$ & $\mathrm{LZ}$ \\
\hline 80 & 20 & 0 & $80 \pm 7$ & $82 \pm 6$ & $76 \pm 7$ & $79 \pm 9$ & 15.6 & 16.0 \\
\hline 20 & 80 & 0 & $175 \pm 11$ & $138 \pm 10$ & $188 \pm 9$ & $151 \pm 11$ & 38.9 & 30.6 \\
\hline 80 & 20 & 10 & $282 \pm 14$ & $275 \pm 11$ & $305 \pm 12$ & $302 \pm 11$ & 62.7 & 61.1 \\
\hline 20 & 80 & 10 & $241 \pm 17$ & $261 \pm 16$ & $256 \pm 13$ & $294 \pm 18$ & 53.6 & 58.1 \\
\hline
\end{tabular}

\subsection{Structural and functional features of the released proteins}

The retention of structural and functional features in the proteins released from the 80/20/10 paper in buffer/saline were tested by various methodological approaches. Retention of secondary structure in lysozyme was studied by far-UV CD (Fig. 2) and confirmed its remarkable structural stability toward exposure at high temperatures, such as those used during the drying step in papermaking. Tryptophan fluorescence spectra of released lysozyme were overlapping those of the original protein (not shown), indicating the absence of modifications in the tertiary structure of this protein.

Binding of iron is a property restricted to native lactoferrin, and can be conveniently monitored spectrophotometrically, given of the characteristic absorbance at $460 \mathrm{~nm}$ of the iron-containing lactoferrin. In spite of the reported thermal sensitivity of lactoferrin and of the high-temperature drying step used in papermaking, lactoferrin released in buffer/saline from the 80/20/10 paper was still capable of binding ferric ions, as shown by the spectral data reported in Fig. 3. In particular, lactoferrin released from paper in buffer/saline was still able to bind 2 atoms $\mathrm{Fe}(\mathrm{III}) / \mathrm{mol}$ protein, as the untreated protein.

\subsection{In vitro antimicrobial activity of incorporated lysozyme and/or lactoferrin paper}

Presence and activity of lysozyme and lactoferrin in paper was evidenced by assay in agar plates containing cell walls of $M$. lysodeikticus (Fig. 4). In the case of the lysozyme-containing paper, the diameter of the lysis halo exceeded that of the paper disk of $11 \pm 0.2 \mathrm{~mm}$. Lactoferrin is not expected to be a lysis agent for

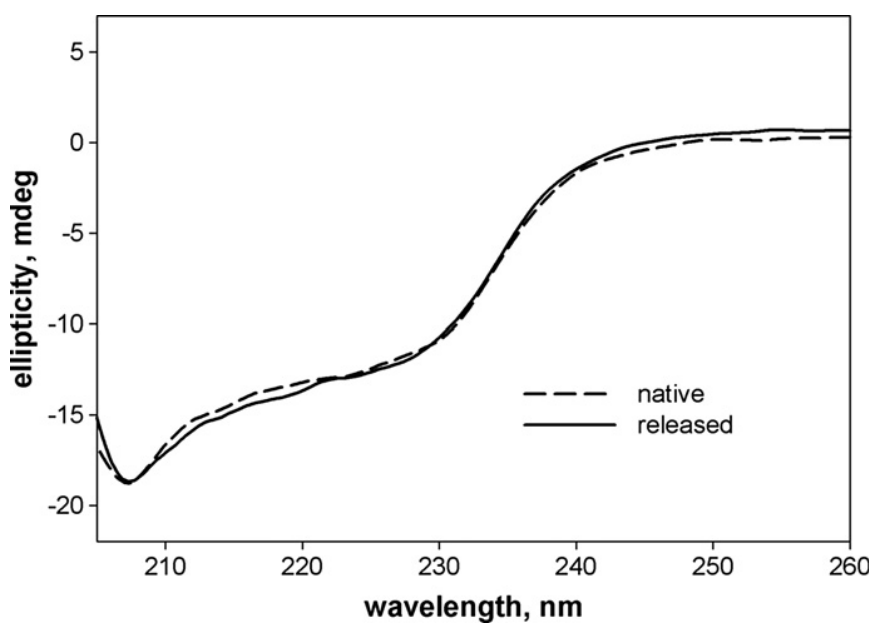

Fig. 2. Far-UV circular dichroism evidence for retention of secondary structure features of native lysozyme after incorporation in paper and release in buffered saline. bacterial cell walls and, accordingly, did not produce a significant lysis halo against M. lysodeikticus cell walls. Paper with the two proteins added showed a lysis halo similar in size to that found for lysozyme alone ( $12 \pm 0.2 \mathrm{~mm}$ ).

Antimicrobial efficacy of the paper containing either or both proteins was assessed by microbiological trials, against $L$. innocua and E. coli, chosen as indicator strains of Gram-positive and Gramnegative bacteria, respectively. Time courses of cell growth in each trial were fitted employing the DMFit software, to estimate growth rate $\left(\mu \max , \mathrm{h}^{-1}\right)$, lag phase duration $(\mathrm{h})$ and final population $\left(\mathrm{Y}_{\mathrm{end}}\right.$, $\log \mathrm{cfu} / \mathrm{ml}$ ) as predicted by the Baranyi and Roberts model (1994). Table 2 shows the efficacy of the various paper samples against L. innocua. The lysozyme-containing paper proved effective in increasing lag phase duration from 1.86 to $5.81 \mathrm{~h}$, but then cells started growing faster than the control ( $\mu$ max 0.73 instead of $0.48 \mathrm{~h}^{-1}$ ) and reached $8.53 \log \mathrm{cfu} / \mathrm{ml}$, with a final $0.5 \log$ reduction. Lactoferrin was found to have a limited effect on lag phase, that increased from 1.86 to $2.57 \mathrm{~h}$. Presence of both proteins gave a marked increase of the lag phase duration, that was prolonged from 1.86 to $6.50 \mathrm{~h}$. Cells then started to grow very fast, with a $\mu$ max of 1.41 instead of $0.48 \mathrm{~h}^{-1}$. Nevertheless, at $24 \mathrm{~h}$ the final population was almost 1 log cycle lower than control.

Table 3 shows the efficacy of the various paper samples against E. coli. Lysozyme-containing paper produced only a modest inhibitory effect. Growth rate was similar to controls, and a modest increase of the lag phase duration from 1.08 to $1.79 \mathrm{~h}$ resulted in a decimal reduction of only $0.25 \mathrm{log} \mathrm{cfu} / \mathrm{ml}$ with respect to control. These data were expected because the muramidase activity of lysozyme against Gram-negative bacteria is reportedly very low. Lactoferrin-containing paper gave a growth rate decrease from 0.51

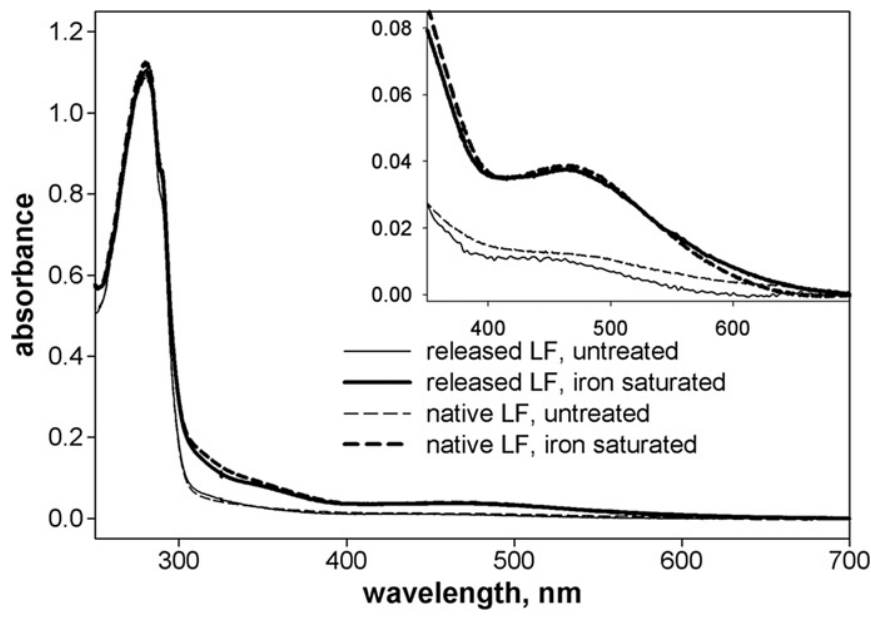

Fig. 3. Absorbance spectra of native lactoferrin (LF) and of lactoferrin released in buffered saline after incorporation in paper. Shown are the spectra of the proteins before and after addition of a 2.2-fold molar excess of iron. Inset: blowup of the spectral region around $460 \mathrm{~nm}$. 


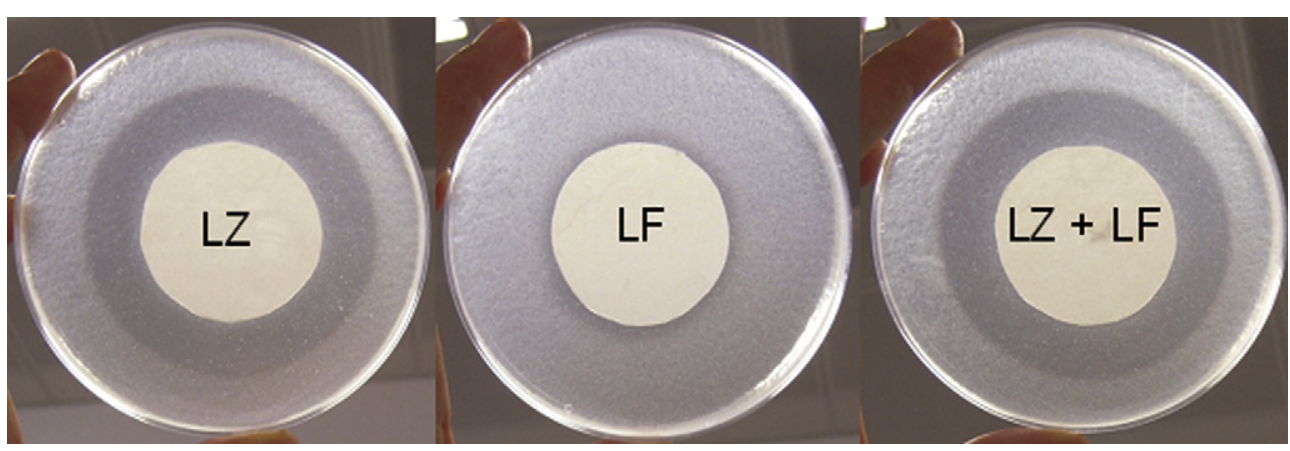

Fig. 4. Lysis halo produced by paper samples incorporating various proteins (or combinations thereof) against cell walls of Micrococcus lysodeikticus.

Table 2

Growth rate, lag phase duration, and final population at $24 \mathrm{~h}$ by L. innocua DSMZ 20649, as predicted by the model of Baranyi and Roberts in the presence of paper containing lactoferrin (LF) and lysozyme (LZ), alone or in combination. The correlation coefficient $R^{2}$ and standard error SEfit are shown. Decimal reduction was computed with respect to control.

\begin{tabular}{|c|c|c|c|c|c|c|}
\hline $\begin{array}{l}\text { Protein incorporated } \\
\text { in the paper }\end{array}$ & $\begin{array}{l}\text { Duration of the } \\
\text { lag phase }(\mathrm{h})\end{array}$ & $\begin{array}{l}\text { Growth } \\
\text { rate }\left(h^{-1}\right)\end{array}$ & $\begin{array}{l}\text { Yend } \\
\text { (log cfu/ml) }\end{array}$ & $R^{2}$ & SE fit & $\begin{array}{l}\text { Decimal } \\
\text { reduction }\end{array}$ \\
\hline None (control) & $1.86^{\mathrm{a}}$ & $0.48^{\mathrm{a}}$ & $9.08^{\mathrm{a}}$ & 0.994 & 0.158 & - \\
\hline$+\mathrm{LZ}$ & $5.81^{\mathrm{b}}$ & $0.73^{\mathrm{b}}$ & $8.53^{\mathrm{b}}$ & 0.993 & 0.212 & -0.55 \\
\hline$+\mathrm{LF}$ & $2.57^{c}$ & $0.43^{\mathrm{a}}$ & $9.10^{\mathrm{a}}$ & 0.999 & 0.053 & +0.02 \\
\hline+ LZ LF & $6.50^{\mathrm{d}}$ & $1.41^{\mathrm{c}}$ & $8.07^{c}$ & 0.993 & 0.189 & -1.01 \\
\hline
\end{tabular}

$\overline{\mathrm{abcd}}$ means within the same column with different superscript letters are different $(P<0.05)$.

to $0.35 \mathrm{~h}^{-1}$, along with an increase of the lag phase duration from 1.8 to $3.25 \mathrm{~h}$. As a result, the final population showed a $1.7 \log$ reduction with respect to the control culture. The best results was evidenced employing the combined proteins, with a final decimal reduction of $2.04 \log \mathrm{cfu} / \mathrm{ml}$.

Interaction between antimicrobials may either be synergistic, additive or antagonistic. A synergistic interaction is defined as a combination effect observed that is greater than the sum of the effects with two agents independently. Additive interactions are when the combined effect is equal to the sum of the individual effects, and antagonistic is when the activity of one compound is reduced in the presence of another (Branen \& Davidson, 2004). Our results highlight that the two indicator strains were sensitive to the antimicrobial effect of proteins in all paper samples, and that the paper containing both lysozyme and lactoferrin was the most effective (2 and $1 \log$ cycle reduction for E. coli and L. innocua, respectively). In $L$. innocua, the lactoferrin/lysozyme interaction may be considered synergistic. By binding iron, lactoferrin could slow the growth of Listeria (as evidenced by the long lag phase), and facilitate lysozyme action. The same mechanism of action has been reported for lactoferrin and nisin against $L$. monocytogenes (Branen \& Davidson, 2004). On the other hand, if assuming that lactoferrin binds to anionic molecules - such as lipotheicoic acid on the bacterial surface of Gram-positive bacteria the resulting decreased negative charge on the cell wall may favor contact between lysozyme and the underlying peptidoglycan (Leitch \& Wilcox, 1999).

As for the effect of the two antimicrobials on E. coli, their interaction may be defined as additive. Lactoferrin is able to increase the permeability of the outer membrane of some Gramnegative strains, by binding to lipid A of lipopolysaccharide, causing liberation of lipid with consequent damage to the cell membrane (Gonzalez-Chavez, 2009). In these conditions, lysozyme may have access to the peptidoglycan, that in Gram-negative bacteria accounts only for $5-10 \%$ of the cell wall and is present beneath the outer membrane of the cell envelope.

\subsection{Antimicrobial activity of active papers on veal "carpaccio"}

Table 4 shows the efficacy of the active papers on total aerobic count (TAC) in samples of veal "carpaccio" (thin slices of veal fillet, meant for consumption as raw meat). Papers containing lysozyme and lysozyme/lactoferrin performed the best on the microbiota in this meat sample, giving almost $1 \log$ cycle reduction with respect to control ( 5.55 and 5.53 vs $6.48 \mathrm{log} \mathrm{cfu} / \mathrm{g})$. It must be noted that in these samples the total count at $48 \mathrm{~h}$ remained close to the initial one, suggesting an inhibitory effect on microbial growth. However, the lactoferrin-only paper was apparently ineffective against growth of this specific meat microbiota, as the bacterial content at $48 \mathrm{~h}$ in this case did not differ from control.

\section{Table 3}

Growth rate, lag phase duration and final population reached at $24 \mathrm{~h}$ by E. coli DSMZ 50902, as predicted by the model of Baranyi and Roberts in the presence of lactoferrin (LF) and lysozyme (LZ), alone or in combination. The correlation coefficient $R^{2}$ and standard error SEfit are shown. Decimal reduction was computed with respect to control.

\begin{tabular}{lllll}
\hline $\begin{array}{l}\text { Protein incorporated } \\
\text { in the paper }\end{array}$ & $\begin{array}{l}\text { Duration of the } \\
\text { lag phase }(\mathrm{h})\end{array}$ & $\begin{array}{l}\text { Growth } \\
\text { rate }\left(\mathrm{h}^{-1}\right)\end{array}$ & $\begin{array}{l}\text { Yend } \\
(\log \mathrm{cfu} / \mathrm{ml})\end{array}$ & $\begin{array}{l}\text { Decimal } \\
\text { reduction }\end{array}$ \\
\hline None (control) & $1.08^{\mathrm{a}}$ & $0.51 \mathrm{a}$ & $9.20^{\mathrm{a}}$ & 0.994 \\
LZ & $1.79^{\mathrm{b}}$ & $0.47 \mathrm{a}, \mathrm{b}$ & $8.95^{\mathrm{b}}$ & 0.128 \\
LF & $3.25^{\mathrm{c}}$ & $0.35 \mathrm{c}$ & $7.50^{\mathrm{c}}$ & 0.992 \\
LZ and LF & $2.68^{\mathrm{d}}$ & $0.43 \mathrm{~b}$ & $7.16^{\mathrm{d}}$ & 0.998 \\
\hline
\end{tabular}

${ }_{\mathrm{abcd}}$ means within the same column with different superscript letters are different $(P<0.05)$. 
Table 4

Mesophilic aerobic population (log CFU/g) in samples of thin veal slices layered on paper containing lactoferrin (LF) and lysozyme (LZ), alone or in combination,before and after storage for $48 \mathrm{~h}$ at $4 \pm 1{ }^{\circ} \mathrm{C}$.

\begin{tabular}{llll}
\hline Time $(\mathrm{h})$ & $\begin{array}{l}\text { Protein incorporated } \\
\text { in the paper }\end{array}$ & $\begin{array}{l}\text { Total aerobic } \\
\text { count }(\log \mathrm{cfu} / \mathrm{g})\end{array}$ & $\begin{array}{l}\text { Decimal } \\
\text { reduction }\end{array}$ \\
\hline 0 & None (control) & $5.34 \pm 0.09^{\mathrm{a}}$ & - \\
48 & None (control) & $6.48 \pm 0.11^{\mathrm{b}}$ & - \\
48 & LZ & $5.55 \pm 0.12^{\mathrm{a}}$ & $-0.93 \mathrm{a}$ \\
48 & LF & $6.30 \pm 0.12^{\mathrm{b}}$ & $+0.18 \mathrm{~b}$ \\
48 & LZ and LF & $5.43 \pm 0.10^{\mathrm{a}}$ & $-1.05 \mathrm{a}$ \\
\hline
\end{tabular}

${ }^{\mathrm{ab}}$ means within the same column with different superscript letters are different $(P<0.05)$.

\section{Conclusions}

This work provides an example of sustainable and active food packaging, in which antimicrobial proteins were incorporated in a matrix of cellulose and carboxymethyl cellulose fibers in the absence of chemical modification. Protein incorporation was efficient, and incorporated proteins may be simultaneously released in a biologically active form by modulating - according to the needs simple physico-chemical parameters. The synergism between the two simultaneously released antimicrobials was evident in tests against common food contaminants. Application of these materials on actual meat samples under conditions similar to those foreseeable for a future practical use of these materials also gave positive results. Future work will indicate whether antimicrobialloaded paper products produced along the lines outlined used here may find other practical uses (e.g., paper liners or wraps) and whether they will be effective to improve the safety and to extend the shelf-life of other raw and processed food products. These studies will also have to verify which factors control the rate of antimicrobial release, and how this can be modulated to fulfill best the various requirements of different foods, also in consideration of their nature, size, shape, and humidity.

\section{Acknowledgments}

Work supported by funds of the EU project FP7-KBBE-2007-1NAFISPACK.

\section{References}

Baranyi, J., \& Roberts, T. A. (1994). A dynamic approach to predicting bacterial growth in food. International Journal of Food Microbiology, 23, 277-294.

Branen, J. K. \& Davidson, P. M. (2004). Enhancement of nisin, lysozyme, and monolaurin antimicrobial activities by ethylendiaminetetraacetic acid and lactoferrin. International Journal of Food Microbiology, 90, 63-74.

Cannarsi, M., Baiano, A., Sinigaglia, M., Ferrara, L., Baculo, R., \& Del Nobile, M. A (2008). Use of nisin, lysozyme and EDTA for inhibiting microbial growth in chilled buffalo meat. International Journal of Food Science and Technology, 43, $573-578$.

Coma, V. (2008). Bioactive packaging technologies for extended shelf life of meatbased products. Meat Science, 78, 90-103.

Cooksey, K. (2000). Utilization of antimicrobial packaging films for inhibition of selected microorganism. In S. J. Risch (Ed.), Food packaging: Testing methods and applications (pp. 2754-2757). Washington, DC: American Chemical Society.

Ellison, R. T., III, \& Giehl, T. J. (1991). Killing of gram-negative bacteria by lactoferrin and lysozyme. Journal of Clinical Investigation, 88, 1080-1091.

Gill, A. O., \& Holley, R. A. (2000). Inhibition of bacterial growth on ham and bologna by lysozyme, nisin and EDTA. Food Research International, 33, 83-90.

Gonzalez-Chavez, S. A., Arevalo-Gallegos, S., \& Rascon-Cruz, Q. (2009). Lactoferrin structure, functions and applications. International Journal of Antimicrobial Agents, 33, 301-308.

Jenssen, H., \& Hancock, R. E. W. (2009). Antimicrobial properties of lactoferrin Biochimie, 91, 19-29.

Leitch, E. C., \& Wilcox, M. D. (1999). Elucidation of the antistaphylococcal action of lactoferrin and lysozyme. Journal of Medical Microbiology, 48, 867-871.

Losso, J. N., Nakai, S., \& Charter, E. A. (2000). Lysozyme. In A. S. Naidu (Ed.), Natural food antimicrobial systems (pp. 185-210). Boca Raton (Florida): CRC Press LLC.

Mascheroni, E., Capretti, G., Marengo, M., Iametti, S., Mora, L., Piergiovanni, L., et al. (2010). Modification of cellulose-based packaging materials for enzyme immobilization. Packaging Technology and Science, 23, 47-57.

Mastromatteo, M. C., Mastromatteo, M., Conte, A., \& Del Nobile, M. A. (2010) Advances in controlled release device for food packaging applications. Trends in Food Science and Technology, 21, 591-598.

Nattress, F. M., \& Baker, L. P. (2003). Effects of treatment with lysozyme and nisin on the microflora and sensory properties of commercial pork. International Journal of Food Microbiology, 85, 259-267.

Nattress, F. M., Yost, C. K., \& Baker, L. P. (2001). Evaluation of the ability of lysozyme and nisin to control meat spoilage bacteria. International Journal of Food Microbiology, 70, 111-119.

Pérez-Pérez, M. C., Regalado-González, C., Rodríguez-Rodríguez, C. A., BarbosaRodríguez, J. R., \& Villaseñor-Ortega, F. (2006). Incorporation of antimicrobia agents in food packaging films and coatings. In R. G. Guevara-González, \& I. Torres-Pacheco (Eds.), Advances in agricultural and food biotechnology (pp. 193-216). Kerala (India): Research Signpost.

Taylor, S., Brock, J., Kruger, C., Berner, T., \& Murphy, M. (2004). Safety determination for the use of bovine milk-derived lactoferrin as a component of an antimicrobial beef carcass spray. Regulatory Toxicology and Pharmacology, 39, $12-24$. 